\title{
Om estetisk praktik och etisk kompass
}

Cecilia Hofsten

- Ni ska nu välja en sång som alla kan och helst tycker om, säger jag till studenterna.

De kikar tysta på varandra. Några spridda förslag på sånger nämns efter en stund, men det är bara ett fåtal som är bekanta med dessa. Tiden går. Till slut måste vi konstatera att det i denna klass med tjugo blivande förskollärare på Stockholms universitet inte tycks existera någon gemensam sång.

- Blinka lilla stjärna, föreslår jag då.

Två studenter kan inte sången, men det får bli den ändå. Alla ställer sig upp och så börjar vi sjunga. Det låter inte övertygande, men kanske är det inte förvånande. Att en grupp vuxna människor som inte känner varandra och som hittills under utbildningen inte gjort någonting praktiskt estetiskt tillsammans, nu ska stå i en ring och sjunga en barnvisa, är kanske att begära för mycket. Jag problematiserar inte detta utan beter mig som om situationen är en självklarhet, eftersom vi trots allt befinner oss i en så kallad musikverkstad. Sedan säger jag som jag ofta viskar till barnen på förskolorna i Hässelby Gård, där jag också arbetar:

- Sjung starkare, så det hörs ända upp till stjärnorna på himmelen!

Vi sträcker på oss och gör några röstuppvärmningsövningar. Vi sjunger igen och igen

och så händer det som jag hoppas på, men som aldrig kan garanteras: sången får liv. Nu förklarar jag att vi ska arbeta med materialet på så sätt att var och en tar sig igenom visan från början till slut. Någon kanske väljer att sjunga den snabbt, någon

Hur du refererar till det här kapitlet:

Hofsten, C. 20I8. Om estetisk praktik och etisk kompass. I: von Schantz, U., Thorgersen, K. and Lidén, A. (red.) De estetiska ämnenas didaktik Utmaningar, processer och protester. Pp. 95-I03. Stockholm: Stockholm University Press. DOI: https://doi.org/Io.I6993/bap.f. License: CC-BY 
annan betydligt långsammare. Vi börjar inte heller samtidigt. Ett myller av röster, ja rent av tjugo stämmor, ljuder nu i rummet. Blickar byts och fnitterleenden anas, men vi genomför ändå denna märkliga utmaning. Sedan ger jag fler instruktioner:

- Du ska nu sjunga som när du syr efterstygn; du backar ibland och tar om. Du kan stanna till på en ton eller en fras som intresserar dig och upprepa den. Lek med melodin. Improvisera. Några får sätta sig i mitten och bara lyssna medan vi andra sjunger. Varsågoda.

Inför varje nytt sångtillfälle fäster jag uppmärksamheten på någonting särskilt. Det kan handla om dynamiken eller om hur vi börjar. Det kan handla om att kasta loss helt vilt eller om att våga vara ensam kvar på slutet. Alla får pröva att blundandes sitta i mitten och lyssna. Efteråt får var och en i publiken kommentera vad de hört. Det är fascinerande hur olika denna musik då har uppfattats. Någon tyckte att det lät fantastiskt vackert, någon annan att det skrämde som i en thriller. Någon kom att tänka på ett gammalt mentalsjukhus och ytterligare någon på atmosfären i en kyrka. Någon upplevde kaoset som obehagligt, medan en annan erfor en frihet av de olika rösterna som det inte gick att kontrollera. Trots de mycket skilda uppfattningarna om musiken vi skapat, uttryckte alla en angelägenhet inför erfarenheten. Det var ingen som var likgiltig. Att förstå hur olika en identiskt klingande artefakt kan upplevas, menar jag är en viktig kunskap att ta med sig i sitt kommande yrke som förskollärare - liksom att som här våga ta sig ton inför varandra.

Det finns professionella musiker som bara behöver träffa sina medmusikanter ett par gånger innan de ska upp på en scen, men då är det viktigt att komma ihåg att de ägnat största delen av sina liv åt musikens hantverk och uttryck. För att ett musikaliskt samspel ska bli meningsfullt för de blivande förskolepedagogerna, krävs det tid. De behöver känna sig tillrätta med uppgiften och varandra, vara i musiken och...vara kvar. Susanna Leijonhufvud formulerar tydligt vad det handlar om:

Musiken kräver sig själv för att helt och fullt kunna visa sig. Epistemologiskt innebär detta att vi aldrig kan lära oss musik 
genom att lära oss om musik. Vi måste de facto musicera för att uppleva musikens hela väsen. Vi kan uppleva en hel del och tala om musik genom att reducera en del av musiken till språket men vi måste vara i musik för att tillfullo uppleva dess väsen. ${ }^{\text {I }}$

Efter att ha varit i Blinka lilla stjärna-improvisationen en god stund lägger jag märke till att samtalen som följer tycks givande för studenterna. Tankarna som formuleras växer så tydligt ur den sinnliga och estetiska mylla som vi nyss besökt och jag undrar om inte också detta är värt en särskild uppmärksamhet. När någon till exempel uttrycker ett obehag inför sångens kaos, kan någon annan student hålla med, men nyansera påståendet genom att berätta att hon kände en lustfylld, pirrande spänning i början av improvisationen. 'Det lät som när man doppar fötterna i vattnet och inte vet om det är för kallt för att gå i.' Jag kan också utmana uppfattningen att det vi gjorde saknade ordning. Var det inte snarare en ovanlig ordning? Ramarna fanns där: var och en skulle ta sig igenom sången på något vis och när alla gjort det var stycket slut. Kan dessa frågor kring ordning av olika slag och kring vad som är fint eller fult ha en giltighet även i andra sammanhang i förskolans vardag? Jag vill gärna tro det.

Att vara i stunden - hur denna stund än är - och att följa med i alla de klingande ögonblick som uppstår när människor sjunger tillsammans, brukar måhända inte betraktas som en kunskapsväg. Det handlar alltså om att uppfatta vad som pågår och själv svara på det.

Om jag istället hade spelat in, skulle studenterna efteråt kunnat lyssna och kritiskt granska resultatet för att inför nästa inspelningstillfälle försöka justera sådant de inte varit nöjda med. Så kan en lärandeprocess naturligtvis också gestaltas. När jag frågar gruppen vad de anser om saken, svarar flera att de inte hade vågat sjunga ut så som de faktiskt gjorde, om jag hade spelat in. Vidare undrar jag hur insikten, att vårt sångskapande $\mathrm{i}$ ett nu är unikt och aldrig någonsin kommer att kunna återskapas, påverkar hängivenheten i närvaron och därmed resultatet. Jag tror den viktigaste nyckeln till ett meningsfullt musicerande är just förmågan till uppmärksamhet och lyssnande.

Det talas mycket om lyssnande i den nutida svenska didaktiska högskolevärld jag kommit i kontakt med. Det brukar ses som 
någonting odelat positivt; ett förhållningssätt vi lärare bör möta barn och studenter med. Men vad innebär egentligen ett lyssnande och är det verkligen klokt att lyssna till allt? Är det möjligt att lyssna med urskiljning och hur utvecklar man i sådant fall denna förmåga? Skulle lyssnande kunna ses som en dygd som behöver övas för att nå sin fulla potential? I ett levande musicerande, oavsett nivå, är det bokstavliga lyssnandet helt centralt. Att musicera tillsammans kan därmed utgöra ett exempel på lyssnandets konst. Som jag förstår lyssnandets kvalitet, är det en öppnande och sinnlig erfarenhet som kan riktas åt olika håll. När vi står där och improvisationssjunger tillsammans är det just detta som blir så tydligt. Var och en behöver samtidigt ha kontakt med sin egen sång, lyssna till den Andres och förhålla sig till den gemensamma klangen i rummet. Frågan som särskilt intresserar mig är om den lyssnande förmåga som utvecklas i ett sådant musicerande, kan komma att påverka och prägla oss som moraliska subjekt $\mathrm{i}$ andra sammanhang. Att ta eget ansvar, att respektera andra människor och att sätta de egna livsvalen i relation till en komplex samtid är inte just det frågeställningar som hör hemma i etikens värld? Estetisk praktik tycks kunna få etikens kompassnål att darra. Jag tror inte demokratin kan fördjupas - kanske inte ens överleva om dess medborgare inte kan lyssna och saknar förmåga till etiskt omdöme, men jag skapar inte musik med barnen på för-skolorna eller studenterna på universitetet i första hand för att träna oss $\mathrm{i}$ demokrati. Vi spelar och sjunger tillsammans för att vi tycker om musiken och här upplever någon sorts mening. Som jag ser det är denna skillnad en viktig poäng.

Tanken att barn bär sitt möjliga växande inom sig och att människorna runt barnen genom att just lyssna kan möta varje barn på bästa sätt, är en syn som stort skiljer sig från en auktoritär tradition där den vuxne alltid vet bäst och därmed får och ska bestämma allting.

Att som pedagog öppna sig för ett lyhört lyssnande gentemot barnen på förskolan, finner jag synnerligen sympatiskt, men att förskolans hela verksamhet ska utgå från vad varje barn vill göra i varje ögonblick, känns för mig riktigt kusligt. Vad händer då med alla de barn som inte vet vad de vill? Och de som vill, men inte vågar? Hur kan ett barn vilja gå till skogen, om hon inte vet 
om att skogen finns? Hur kan ett barn vilja börja spela sax eller trumpet, om hon aldrig någonsin hört dessa instrument? Hur kan nya reflektionsprocesser väckas, om motstånd aldrig ges? En miljö som menar allvar med ett lyssnande förhållningssätt, måste uppmuntra både barn och vuxna att lyssna till varandra.

Det finns ett gränsland där det förtrogna möter det främmande. Den tyske hermeneutikern Hans-Georg Gadamer menar att det vi människor redan kan och känner till utgör grunden för vår förförståelse inför mötet med det nya och att det är just utifrån vår förförståelse som tolkningen av det främmande görs. ${ }^{2}$ Med detta synsätt lever en människas liv vidare i den egna blicken. Även erfarenheten av ett återkommande, lyssnande musicerande på förskolan kan därmed bidra till hur vi långt senare kommer att möta och förstå vår omvärld. Jag önskar att förskolans pedagoger kan se det som sin uppgift att skapa möjligheter för barn att erfara hur märkliga och främmande aktiviteter kan utmana det välbekanta och att det kan komma någonting nytt och kul ut ur det.

Suzanne Osten - dramatiker, regissör och före detta konstnärlig ledare för Unga Klara i Stockholm - konstaterar att en ny romantisk myt tagit sig in i debatten, nämligen den att barn alltid kan skapa själva och inte behöver några kunniga, vuxna förebilder. ${ }^{3}$ Att erkänna sig själv som förebild är inte att tro sig om att i alla lägen veta bäst. Som jag ser det handlar det istället om att uppfatta barns villighet att imitera och att inse att en vuxen inför ett litet barn därför alltid $\ddot{a} r$ en förebild och att detta förpliktigar till att vara under utveckling. Det kan till exempel innebära att ibland vända blicken mer mot sig själv och mindre mot barnen - som att själv sjunga istället för att sitta tyst och uppmana barnen att göra det. Att erkänna sig som förebild inför ett barn, utesluter inte heller en rörelse åt andra hållet, där barnet är den som förebildar.

Mina intryck, efter närmare tre decenniers arbete som rytmikpedagog på olika förskolor i Stockholmstrakten, är att musikaktiviteter drastiskt har minskat i förskolans värld. I läroplanen står dock fortfarande detta att läsa:

Att skapa och kommunicera med hjälp av olika uttrycksformer såsom bild, sång och musik, drama, rytmik, dans och rörelse liksom 
med hjälp av tal och skriftspråk utgör både innehåll och metod i förskolans strävan att främja barns utveckling och lärande. ${ }^{4}$

Om en förskola har ambitionen att låta estetisk verksamhet ta plats, menar jag att även barnens pedagoger måste ha upplevt en estetisk praktik för att alls kunna uppfatta och uppskatta den. Studenterna behöver med andra ord_erbjudas mycket tid och ledning under utbildningen för att komma vidare i sin egen process. Risken blir annars att de inte kan uppfatta värdet av barns ljudliga utforskande och att de estetiska ämnena, flämtande för sin överlevnad, endast får agera lockbete åt någonting annat - som när musikens hela funktion blir att sjunga alfabetet på engelska för att det ska fastna bättre.

Om jag som vuxen kommunicerar med ett barn som ännu inte behärskar sitt verbala språk så väl och till exempel undrar hur barnet mår, kanske jag får ett "bra” tillbaka. Ställer jag samma fråga till samma barn men ger henne en trumma att svara med, kommer jag alldeles säkert att få ett rikare svar. Samtidigt är svaret förstås otydligare; det består ju bara av en serie slag mot trummans skinn. Jag menar absolut inte att dessa spelade rytmer är några exakta representationer och därmed skulle kunna översättas enligt en manual, där varje särskild rytm motsvarar ett specifikt känsloläge, men ett nyfiket lyssnande till trumspelet kommer antagligen leda till uppfattningen att detta svar är mer nyanserat och därmed rikare än vad som rymdes i ordet "bra". Denna kommunikationslek har jag utvecklat med barn på förskolor och därifrån tagit med till studenterna på universitetet.

Att orden, och än mindre det rationella tänkandet, inte når in i tillvarons alla vrår kan väl knappast någon människa på allvar betvivla, men eftersom de icke-verbala världarna är utrotningshotade i det nutida utbildningslandskapet, verkar det nödvändigt att med ord försöka argumentera för kunskapen bortom orden. 'Låt oss bara leva utan den naiva förhoppningen att ordet alltid för oss närmare verkligheten, att transformationen till det verbala är ett nödvändigt villkor för förståelse även av de språk som nyttjar andra medel.'s Så avslutar vetenskapsteoretikern Sven Andersson sitt bidrag i antologin Mellan konst och vetenskap och jag är beredd att hålla med. Jag tror att musik kan uttrycka sådant som 
det verbala språket inte förmår, men det blir därmed omöjligt att säga vad.

När Chicagofilosofen, tillika professorn, Martha C Nussbaum ger sig i kast med frågor kring estetisk verksamhet och etik, är det beröringen dem emellan som är hennes utgångspunkt. I boken Not for profit, presenterar hon sin syn på konstens och humanioras nödvändighet för demokratin. ${ }^{6}$ I ett samhälle där den ekonomiska ordningen med sin galopperande tillväxtförväntan skruvar upp effektivitetskraven alltmer, riskerar skillnaderna i villkor människor emellan att öka än mer, enligt Nussbaum. Hon anser att kritiskt tänkande, självreflektion och förmåga att sätta sig in i andra människors inre liv är de essentiella kvaliteter en levande demokrati kräver. När Nussbaum lyfter vikten av konstnärlig pedagogisk verksamhet på förskolor, grundskolor och universitet, gör hon det alltså inte utifrån bilden av dessa ämnen som lyx, utan tvärtom som nödvändiga. Ur dessa verksamheters upplevelser kan nämligen en önskan och en förmåga vakna till liv att öppna sig mot andra, byta perspektiv, låta sig omskakas, få syn på sig själv och rent av förvandlas. Nussbaum ger exempel på hur körsång kan bli en arena där människor med olika bakgrund faktiskt kan mötas i ömsesidig respekt. Hon uppmärksammar särskilt möjligheten i att sjunga eftersom det så tydligt inbegriper kroppen. Att sjunga är att vara sårbar.

Nussbaum menar att nedskärningarna av de humanistiska ämnena främst kan förstås utifrån det faktum att de inte omedelbart genererar ekonomisk tillväxt. Hon ser denna utveckling som ett allvarligt hot mot demokratin. I en kultur där konkurrensen inte var så hård och den tekniska utvecklingen inte ständigt prioriterades framför annan utveckling, skulle säkert ett levande musicerande i skola och förskola kunna blomstra, eftersom det numera finns många studier som bekräftar hur ett aktivt musicerande kan stimulera hälsan, den kognitiva utveck-lingen och den sociala kompetensen. Situationen i dagens Sverige, som jag tänker mig den, är att ett levande musicerande med barn inte tas på allvar för att musiken är så svår att fånga; omöjlig att definiera, klassificera, värdera och behärska. Den levande musiken går inte ens att spara i hela sin totala upplevelse. Den finns egentligen bara då den klingar. 
Att själva musiken skulle vara utrotningshotad tycks inte vara fallet $i$ en tid och en kultur som har svårt att ens erbjuda några tysta miljöer. Men det är en avgörande skillnad mellan att låta inspelad musik stå på i bakgrunden och att själv skapa musik med hjälp av sin egen kropp och sitt eget aktiva lyssnande. Min oro handlar om det enkla och levande musicerandets överlevnadsprognos i förskolan. Det är mycket som tyder på att denna oro är befogad. Nussbaum bekräftar att musik och övriga konstnärliga och humanistiska ämnen, har fått stryka på foten i så gott som alla nationer från förskola till universitet. Jag skulle vilja pröva en tanke som ändå skjuter in en strimma hopp i detta dystra scenario. Om det är så att musik är någonting grundläggande mänskligt som utgår från våra kroppars gung, vår egen andning och vår lust till kontakt med livet, oss själva och varandra i ett samspel, kommer musiken att bestå så länge som mänskligheten gör det. Kanske kan det enkla och levande musiceradet äga sin identitet just utifrån sin oförmåga att konkurrera i en global ekonomi. I mötet med en trudelutt, stöter vinstmaximeringens drivkrafter på sin gräns.

Jag tycker mycket om Nussbaums tankar om att sång kan öppna dörrar till ett känsligt inre. Denna sensibilitet blir extra synlig i mötet med små barn, men egentligen följer den med som en möjlighet livet igenom. Studenterna på förskollärarlinjen vid Stockholms universitet, visar också de sin sårbarhet när de generas över att sjunga tillsammans, men ändå gör det. När jag frågade en student hur hon kan våga prata men inte sjunga, svarade hon: 'ja men att sjunga är mer naket'. Sårbarhet, nakenhet och sensibilitet är någonting att vårda eftersom de utgör grundvillkor för att vara människa. Att ha kontakt med denna sin egen skörhet är inte bara en broms när yttre förväntningar eller inre röster kräver för mycket. Det är också ett verksamt vaccin mot projektioner och andra enkla lösningar av komplexa problem.

\section{Slutnoter}

I. Leijonhufvud, 20I I:I I. Sångupplevelse - en klingande bekräftelse på min existens $i$ världen.

2. Gadamer, I997:I42. Sanning och metod - i urval. 
3. Osten, 2013. "Maktperspektiv och Konstens betydelse för barn”, Mänskliga Rättighetsdagarna i Kulturhuset i Stockholm 20I3-I I-I4. 4. Läroplan för förskolan Lpfö 98 Reviderad 20I6:7.

5. Andersson, I995. Har musiken något att säga? Mellan konst och vetande.

6. Nussbaum, 2010. Not for profit: why democracy needs the humanities.

\section{Referenser}

Andersson, S. I995. Har musiken något att säga? Mellan konst och vetande. Göteborg.

Gadamer, H-G. I997. Sanning och metod - i urval. Göteborg: Daidalos.

Leijonhufvud, S. 20I I. Sångupplevelse - en klingande bekräftelse på min existens $i$ världen. Stockholm.

Läroplan för förskolan, Lpfö 98. Skolverket. Reviderad 2016.

Nussbaum, M. C. 2010. Not for profit: why democracy needs the humanities. Princeton: Princeton University Press.

Osten, S. ”Maktperspektiv och konstens betydelse för barn”, Mänskliga Rättighetsdagarna i Kulturhuset i Stockholm 20I3-I I-I4. 
